\title{
INNOVATIVE EDUCATIONAL PROGRAM FOR BIOGAS PRODUCTION CARRIED OUT AT UNIVERSITY OF HRADEC KRÁLOVÉ (CZ) AND AT UNIVERSITY OF OPOLE (PL)
}

\author{
INNOWACYJNY PROGRAM EDUKACYJNY DOTYCZĄCY WYTWARZANIA \\ BIOGAZU REALIZOWANY NA UNIWERSYTETACH \\ W HRADEC KRÁLOVÉ (CZ) I OPOLU (PL)
}

\begin{abstract}
Recently, there is a growing pressure on a rapid construction of agricultural biogas plants, particularly in the Czech-Polish border region. It is an area with large expanses of agricultural land which can serve to supply biogas plants with biomass. This strategy should contribute to harmonize the common agricultural policy of the European Union. A need for qualified operators of these stations on this territory is also increasing. Therefore we first include a demonstration of an education program for students in the field of agricultural waste anaerobic fermentation and biogas production. We present here the first part of an innovative approach which we use in the teaching program "Physico-technical Measurements and Computer Technology" at the Faculty of Science at the University of Hradec Kralove and also in the education of internshipers from the Faculty of Natural Sciences and Technology at the University of Opole. There are requirements to fulfil labour market expectations and to make this subject more attractive for the students. Students' theoretical and practical preparation constitutes a comprehensive source of knowledge and skills required in a real life job. Joined theoretical and practical knowledge gained by students, reinforced by the skills developed during task analysis followed by their solution, provides the future graduate higher quality abilities and better position in the labour market.
\end{abstract}

Keywords: biogas plants, continuous measurement and modelling

\section{Introduction}

According to the previous evaluations, currently there is a lack of technical and science graduates on a labour market who can meet the needs of employers. Current development requires knowledge of modern measuring instruments principles, measurement methods, data analysis and creation of mathematical and statistical models of observed phenomena (including their validation) from workers with this specialization. Graduates are usually familiar with theoretical foundations of these topics, but they are often unable to use the

\footnotetext{
${ }^{1}$ Department of Physics, University of Hradec Králové, Rokitanského 62, 50003 Hradec Králové, Czech Republic

${ }^{2}$ EMPLA, Za Škodovkou 305/5, 50311 Hradec Králové, Czech Republic

${ }^{3}$ Chair of Biotechnology and Molecular Biology, University of Opole, ul. kard. B. Kominka 6, 45-032 Opole, Poland

* Corresponding author: jan.loskot@uhk.cz
} 
measuring instruments autonomously, evaluate measured data and use software for creating models. Therefore, they usually have only a small chance on the labour market and it also often discourages them from accepting the proposed job.

The aim of our efforts is to improve students' qualification by introducing innovation in bachelor's degree teaching programs oriented on physical and technical disciplines. We modify these programs in close collaboration with the University of Opole and with employers on both sides of the Czech-Polish border to better meet the needs of the labour market.

We perform these actions via a modern form of excursions and internships organized in accredited professional companies with high innovation level. Supplementing the theoretical knowledge acquired at a university by hands-on trainings not only increases the students' skills, but mostly also removes their inhibitions to accept this challenging job on the labour market. The ability to use modern measuring devices, correctly interpret measurement results and work with mathematical and statistical models also gives them a career development prospect in the field they studied.

We primarily focused on the subject "Continuous monitoring systems for environmental protection and health promotion" in the third year of bachelor's degree program "Physico-technical Measurements and Computer Technology". Teaching each of the thematic units covered by this subject consists of three parts: I) a lecture where students gain basic theoretical information about the technology, principles of the measurement instrumentation, methods for handling process parameters obtained in continuous measurement and also about the impact of the technology on the environment, II) a full-day excursion to an appropriate professional company where students learn about continuous measurements in practice and about safety precautions, III) a practical exercise in a computer classroom where students learn to evaluate technological data from a particular company and create mathematical and statistical models of the environmental impact of the technology. At the end of the semester, after attending all the excursions, each student selects one of available topics for the following mandatory week internship in a professional company. In the company, a group of three or four students collectively works on a specified project, which is usually related to modelling a certain phenomenon or the environmental impact of the technology. The best works will be presented at annual environmental student scientific conferences. Depending on the level of the work, the students will participate in domestic, eventually international conferences (MED, ECOpole - Forum of Young Scientists etc.) [1].

Recently, there is a growing pressure on a rapid construction of agricultural biogas plants on the territory of Poland [2,3] and a need for qualified operators of these stations on the Czech territory is also increasing. That is why we first include a demonstration of the education system for students of above mentioned program at the Faculty of Science at the University of Hradec Kralove and internshipers from the Faculty of Natural Sciences and Technology at the University of Opole in the field of anaerobic fermentation of agricultural waste and biogas production.

\section{Theoretical background}

Anaerobic fermentation and biogas production is a natural complex biochemical process which occurs entirely spontaneously in nature (e.g. at the bottom of seas and lakes). Several types of microorganisms in the absence of atmospheric oxygen participate in this 
process [4]. Products of one group of microorganisms serves as substrate for the next group. Biochemical conversion processes are interdependent in such a way that no accumulation of intermediate products occurs in the system. The anaerobic process is conducted by microorganisms from two biological realms, Bacteria and Archaea. The fundamental theoretical stoichiometric equation of methane production from an organic compound with a molecular formula of $\mathrm{C}_{x} \mathrm{H}_{y} \mathrm{O}_{z}(x, y, z$ are the numbers of atoms of elements $\mathrm{C}, \mathrm{H}, \mathrm{O}$ ) is:

$$
\mathrm{C}_{x} \mathrm{H}_{y} \mathrm{O}_{z}+\left(x-\frac{y}{4}-\frac{z}{2}\right) \mathrm{H}_{2} \mathrm{O} \rightarrow\left(\frac{x}{2}+\frac{y}{8}-\frac{z}{4}\right) \mathrm{CH}_{4}+\left(\frac{x}{2}-\frac{y}{8}+\frac{z}{4}\right) \mathrm{CO}_{2}
$$

According to the current conception, the process proceeds in four stages: hydrolysis, acidogenesis, acetogenesis and methanogenesis (Fig. 1).

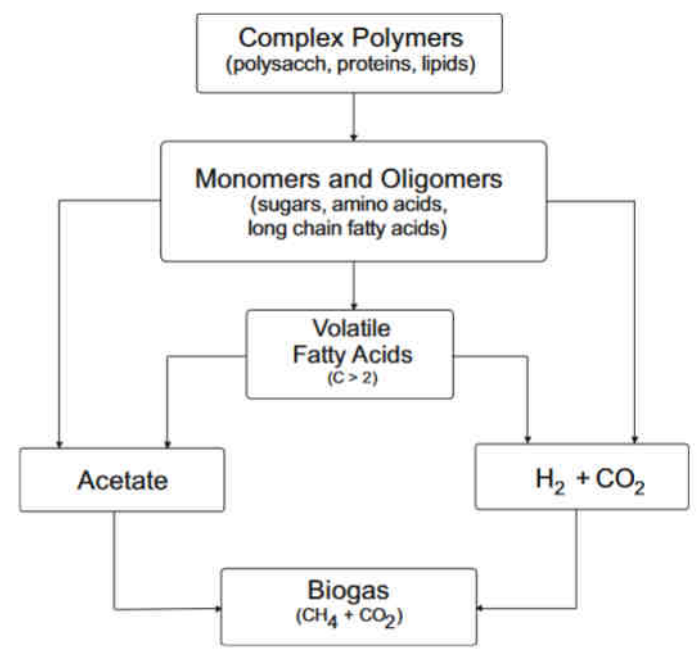

Fig. 1. A diagram illustrating four stages of methanogenesis [5]

During hydrolysis, a decomposition of polymeric materials (polysaccharides, lipids, proteins) to mono or oligomers occurs. In the process of polymer materials decomposition, extracellular enzymes of hydrolytic bacteria are involved. The hydrolysis rate and degree varies for different materials. For sugars, hemicellulose and cellulose are hydrolyzed easily, whereas pectins and starch require a longer period and lignin is virtually non-hydrolysable. The hydrolysis degree of proteins is lower than that of sugar, and often lower compared to fats. Hydrolysis becomes a limiting factor for anaerobic fermentation in the case when hardly degradable materials enter into it.

Acidogenesis follows the hydrolysis, facultative or obligatorily anaerobic acidifying bacteria participate in it. The intermediates of hydrolysis are further decomposed to lower fatty acids, carbon dioxide and hydrogen.

During acetogenesis, acetic acid, elemental hydrogen and carbon dioxide are formed. Because the previous stages are realized by facultatively anaerobic microbial communities, acetogenesis runs after exhaustion of oxygen already in an anaerobic environment. This creates conditions for a balanced development of symbiotic methanogenic microorganisms. 
Methanogenesis is the last phase of anaerobic fermentation, its product is biogas with the main components methane and carbon dioxide [6]. Strictly anaerobic methanogenic microorganisms involved in methanogenesis belong to the realm of Archae and they reportedly belong to the oldest organisms on the Earth.

Each stage proceeds with a different speed. That is why optimal balance in kinetics of the stages is very important for the stability of organic substrates methanization process. The first and limiting methanization stage is hydrolysis which determines the rate of initial material decline, microbial organisms growth as well as biogas production.

The hydrolysis may be considered as a first order chemical reaction and described by the equation:

$$
\frac{d S}{d t}=-k_{1} \cdot S \cdot X
$$

where $S$ is the concentration of hydrolyzed substrate, $t$ is time, $k_{1}$ is the hydrolysis rate constant and $X$ is the concentration of organisms that catalyze the reaction. When we put $X=1$ (we assume constant concentration of organisms) and integrate both sides of the equation (2) we obtain a formula for the amount of substrate at the time $t$ :

$$
S=S_{0} \cdot e^{-k_{1}}
$$

where $S_{0}$ is the concentration (amount) of the substrate at the time of the hydrolysis start. The hydrolysis rate constant $k_{1}$ is dependent on local conditions.

The time dependency of biogas creation from the substrate is described by the equation:

$$
V_{B}=B_{0} \cdot\left(1-e^{-k_{4} t}\right)
$$

where $V_{\mathrm{B}}$ is the yield of methane, $k_{4}$ is a kinetic parameter and $B_{0}$ is a maximum yield of methane. The $B_{0}$ parameter is a limit value of methane yield in a batch experiment $[4,7]$ :

$$
\lim _{t \rightarrow \infty} V_{B}=\lim _{t \rightarrow \infty}\left[B_{0} \cdot\left(1-e^{-k_{4} t}\right)\right]=B_{0}
$$

In practice, in a technology called wet anaerobic fermentation of agricultural substrates, so called flow (continuous) fermentation is preferably used. This approach consists in a continuous slow inflow of nutrients into the system while continuous withdrawing the fermented medium. This provides enough nutrients throughout the fermentation, and possible adverse metabolites which inhibit the growth of microorganisms are diluted [7]. The main parameter characterizing the continuous process is so called dilution rate $D$ which is defined as:

$$
D=\frac{F}{V}
$$

where $F$ is the volumetric inflow of nutrients and $V$ is the volume of the substrate together with the fermenter culture. The reciprocal of $D$ is called retention time $H$ [day]. It specifies the time in which the entire volume of the substrate with the fermenter culture is replaced.

When the fermentation is continuous and the fermenter volume is constant, the outflow rate of the fermented medium is the same as the inflow rate of the nutrient. The time dependency of biogas generation is expressed by equation:

$$
\frac{d B}{d t}=-k_{B} Y_{B / S} \frac{d S}{d t}
$$


where $B$ is the amount of generated biogas, $S$ is the amount of substrate, $Y_{B / S}$ is a biogas yield coefficient and $k_{\mathrm{B}}$ is a proportionality constant.

To express the continuous methanization process progression of agricultural substrates with a predominance of cattle slurry, Chen and Hashimoto [8] suggested the following mathematical model:

$$
V_{M}=B_{0} \cdot\left(1-\frac{K}{H \cdot \mu_{\max }+K-1}\right)
$$

where $V_{M}\left[\mathrm{~m}^{3} \mathrm{CH}_{4} / \mathrm{kg} \mathrm{VS}\right]$ is the volumetric methane production depending on the substrate delay in the fermenter, $B_{0}$ is the maximum yield of methane $\left[\mathrm{m}^{3} \mathrm{CH}_{4} / \mathrm{kg} \mathrm{VS}\right]$ from the substrate, $H$ is the retention time [day], $K$ is Hashimoto kinetic constant, $\mu_{\max }$ is the maximum growth rate of microorganisms $\left[\right.$ day $\left.^{-1}\right] . B_{0}$ depends on temperature and type of substrate; the maximum growth rate also varies with temperature (optimal values for $\mu_{\max }$ are $40-42^{\circ} \mathrm{C}$ for mesohpilic bacteria and $60-62^{\circ} \mathrm{C}$ for thermophilic bacteria). The kinetic constants were obtained in laboratory studies, their correctness was proven by using them to predict the results of methanization in a fermenter [9-11].

\section{Visits in companies}

A full-day excursion of students into an agricultural biogas plant is described in our previous article [12].

For anaerobic fermentation in agricultural biogas plants, substrates form purposeful crops (e.g. maize) as well as remains of agriculture and food industry is used. Agricultural biogas contains low amount of unwanted substances, because the composition of the substrates is rather homogenous (Table 1). Purification of agricultural biogas is easier compared to purification of the biogas from residual sewage sediments or landfills.

Table 1

Composition of agricultural biogas (prepared according to [5])

\begin{tabular}{|c|c|c|}
\hline Component & Symbol & Content agricultural biogas [\%] \\
\hline Methane & $\mathrm{CH}_{4}$ & $37-67$ \\
\hline Carbon dioxide & $\mathrm{CO}_{2}$ & $24-40$ \\
\hline Hydrogen sulphide & $\mathrm{H}_{2} \mathrm{~S}$ & $(15-427) \cdot 10^{-4}$ \\
\hline Oxygen & $\mathrm{O}_{2}$ & $1-5$ \\
\hline Nitrogen & $\mathrm{N}_{2}$ & $10-25$ \\
\hline
\end{tabular}

Estimation of the methane production yield from a substrate can be based on so called feed analysis which uses a formula that gives directly the volume of methane converted to normal conditions $\left(0^{\circ} \mathrm{C}, 101.3 \mathrm{kPa}\right.$, dry gas) and 1 kilogram of dry matter. The formula expresses the gain of methane from various components of the substrate:

$$
V_{F}=P X_{1}+L X_{2}+F X_{3}+N X_{4}
$$

where $V_{F}$ is the volume of methane from proteins $P$, lipids $L$, cellulose $F$ and nitrogen-free substances $N$. Values of $P, L, F$, and $N$ are specified by relevant methods, empirical coefficients $X_{1}-X_{4}$ which express the yield of biogas corrected by the anaerobic degradability are determined experimentally from relatively large amounts of data.

The main substrate which is currently used for agricultural biogas production is slurry. In the slurry there is a low concentration of organic matter, so it is suitable to supplement 
the feed with various organic substrates which are available on the local market. Using these co-substrates serves to optimize the kinetics of the fermentation process through a better carbon to nitrogen ratio configuration. This increases the efficiency and economic viability of the device [2]. In Table 2 composition of various agricultural substrates is presented.

Contents of dry matter and organic dry matter in various agricultural substrates, theoretical yield of biogas from these substrates [3]

\begin{tabular}{|c|c|c|c|c|c|}
\hline \multirow[b]{2}{*}{ Substrate } & \multirow[b]{2}{*}{$\begin{array}{l}\text { Dry matter } \\
\text { content }[\%]\end{array}$} & \multirow[b]{2}{*}{$\begin{array}{c}\text { Organic dry } \\
\text { matter content } \\
{[\% \text { d.m. }]}\end{array}$} & \multicolumn{3}{|c|}{ Theoretical yield of biogas } \\
\hline & & & $\begin{array}{c}\text { from } 1 \mathrm{~kg} \text { dry } \\
\text { weight matter } \\
{\left[\mathrm{dm}^{3}\right]}\end{array}$ & $\begin{array}{c}\text { from } 1 \mathrm{~kg} \text { wet } \\
\text { weight matter } \\
{\left[\mathrm{dm}^{3}\right]}\end{array}$ & $\begin{array}{c}\text { methane content } \\
\text { in biogas } \\
{[\%]}\end{array}$ \\
\hline Cattle slurry & $8-11$ & $75-82$ & $200-500$ & $20-30$ & 60 \\
\hline Pig slurry & ca. 7 & $75-86$ & $300-700$ & $20-35$ & $60-70$ \\
\hline Chicken manure & ca. 32 & $63-80$ & $250-450$ & $70-90$ & 60 \\
\hline Cattle manure & ca. 25 & $68-76$ & $210-300$ & $40-50$ & 60 \\
\hline Pig manure & $20-25$ & $75-80$ & $270-450$ & $55-65$ & 60 \\
\hline Corn silage & $20-35$ & $85-95$ & $450-700$ & $170-200$ & $50-55$ \\
\hline Grass silage & $25-50$ & $70-95$ & $550-620$ & $170-200$ & $54-55$ \\
\hline Rye silage (GPS) & $30-35$ & $92-98$ & $550-680$ & $170-220$ & ca. 55 \\
\hline Sugar beet & 23 & $90-95$ & $800-860$ & $170-180$ & $53-54$ \\
\hline Beet leaves & 16 & $75-90$ & $550-600$ & ca. 70 & $54-55$ \\
\hline Grain decoction & $6-8$ & $83-88$ & $430-700$ & $30-50$ & $58-65$ \\
\hline Potato decoction & $6-7$ & $85-95$ & $400-700$ & $36-42$ & $58-65$ \\
\hline Molasses & $80-90$ & $85-90$ & $360-490$ & $290-340$ & $70-75$ \\
\hline Brewery waste & $20-25$ & $70-80$ & $580-750$ & $105-130$ & $59-60$ \\
\hline $\begin{array}{c}\text { Swine stomach } \\
\text { contents }\end{array}$ & $12-15$ & $75-86$ & $250-450$ & $20-60$ & $60-70$ \\
\hline $\begin{array}{l}\text { Cattle stomach } \\
\text { contents }\end{array}$ & $11-19$ & $80-90$ & $200-400$ & $20-60$ & $58-62$ \\
\hline
\end{tabular}

\section{A practical exercise in a computer classroom}

Understanding the principles of organic substrates anaerobic fermentation is relatively demanding, especially for non-chemically oriented students.

Therefore, in our teaching we modified the diagram of the four-stage process (Fig. 1) in order to better distinguish the particular stages of methanogenesis. Then we linked this diagram with mathematical formulas which express the kinetics of the process. Finally, we added a graphical representation of the substrate decrease process and the production of methane. All interconnected graphics are shown in Figure 2.

During our practical lessons, students at first learn to process the data acquired by continuous measurement in a selected company. They process these data using statistical software, especially Matlab, and they learn to display the data correctly (Fig. 3). The gained knowledge of working with the statistical software is useful for the students also in other study subjects and for working on their final theses. Using real data acquired in a company is more motivating for the students than using artificial data, because they see the link between the data acquisition, its processing and practical applications.

Figure 3 shows technological data acquired by a continuous measurement in a biogas plant. The students obtained these data within their excursion in an agricultural biogas plant and they had the task to clearly arrange these data for the next exercise. 


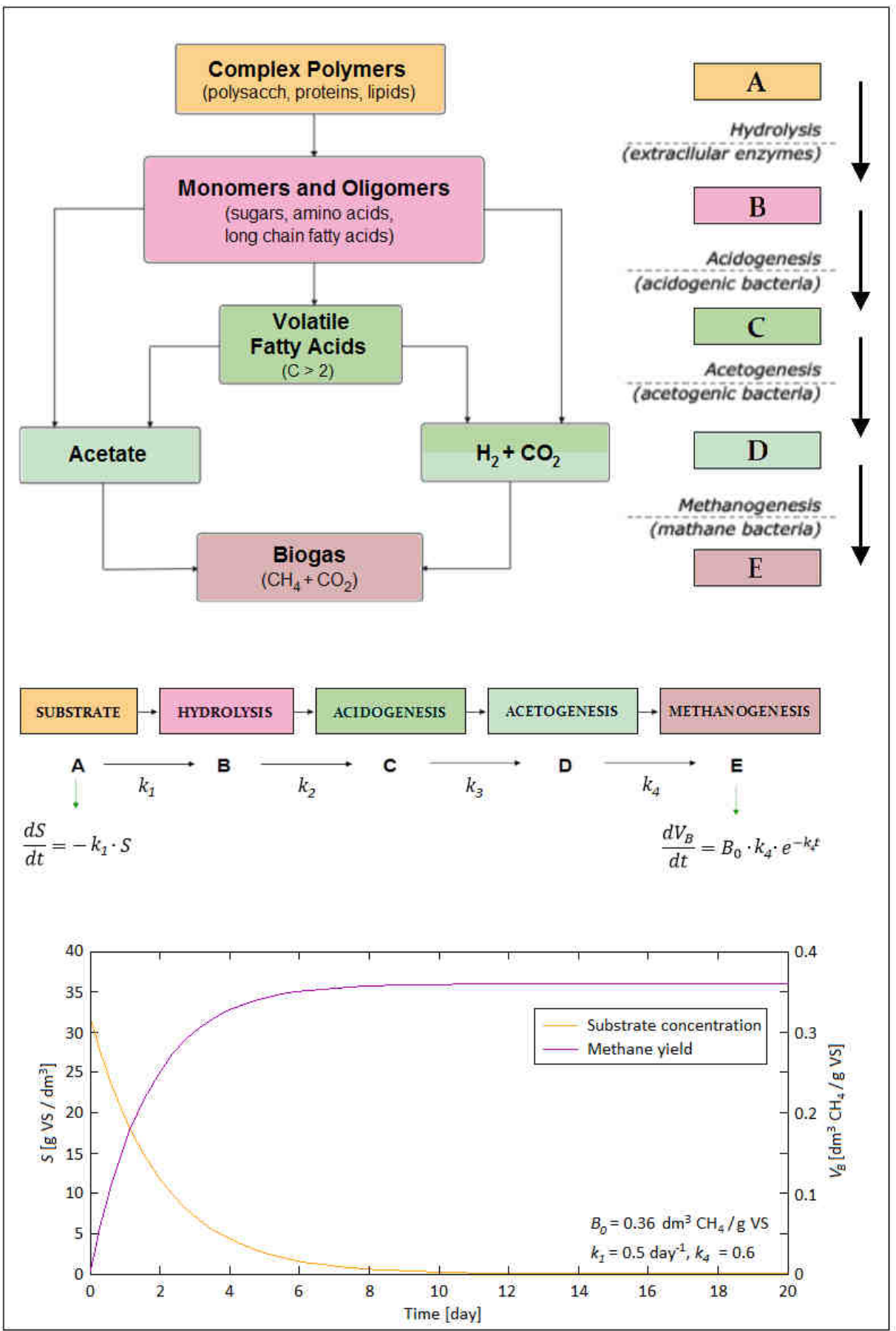

Fig. 2. Proposed graphical representation of processes which occur during biogas production, modified diagram [5] 


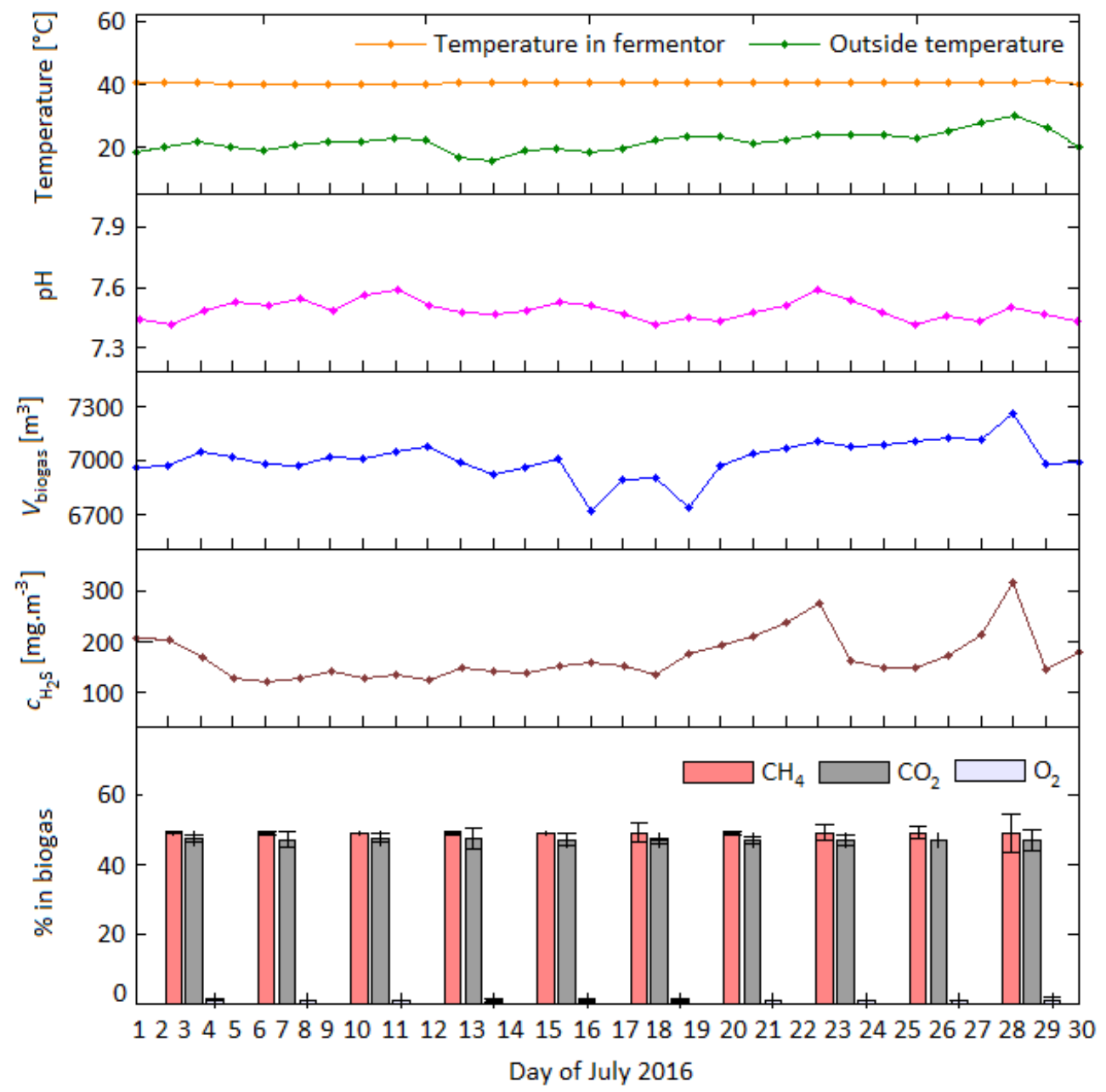

Fig. 3. Technological data acquired by continuous measurement in a biogas plant

In the next step students compare the measured data with mathematical models of the processes $[8,9]$. They discuss how well the mathematical model fits the measured data and what could be the causes of differences. Detailed description of applying mathematical models in physical-technical disciplines is provided in [16]. In our educational approach, we emphasize the facts given there that it is necessary to consider the conditions of the model validity and it is always the modeller who takes responsibility for the modelling results; therefore he has to think thoroughly about the connection between the model and the modelled reality.

For example, in Figure 2, which shows the result of a mathematical model, the curve of the produced methane ("Methane yield") initially increases more quickly than the corresponding curve obtained from measured data. The curve plotted from the measured data contains a point of inflection whose presence does not result from the mathematical 
model. The reason of this is that the mathematical model does not include a detailed description of processes during the fermenter startup (the microorganisms must first proliferate, which makes the initial phase of the biogas production slower). In this way, the students recognize advantages and limitations of mathematical models, so they are better prepared for interpretation of them in practice.

For better understanding of the taught mathematical relationships and improving the ability to use them in practice $[10,11]$ etc. we prepared also several calculation exercises for students. Here we present some of them:

Calculation exercise 1: Time dependence of substrate concentration during hydrolysis $[10,12]$.

In a batch experiment, the initial concentration of substrate $S_{0}=32 \mathrm{~g} \mathrm{VS} / \mathrm{dm}^{3}$. The hydrolysis rate constant $k_{1}=0.5$ day $^{-1}$. Constant concentration of catalyzing organisms is assumed.

Tasks:

a) Calculate the values of the substrate concentration $S$ after 2, 4, 8 and 15 days.

b) Determine when the substrate concentration $S$ falls to $1 / 4$ of its initial value.

Solution:

a) Hydrolysis is described by a differential equation

$$
\frac{d S}{d t}=-k_{1} \cdot S
$$

which can be written in an integral form

$$
S=S_{0} \cdot e^{-k_{1} t}
$$

Into this equation we substitute $S_{0}=32 \mathrm{~g} \mathrm{VS} / \mathrm{dm}^{3}, k_{1}=0.5$ day $^{-1}$ and gradually $t=2,4$, 8 and 15 days for particular periods. After the calculation we obtain the results: $S(t=2) \doteq 11.77 \mathrm{~g} \mathrm{VS} / \mathrm{dm}^{3}, S(t=4) \doteq 4.33 \mathrm{~g} \mathrm{VS} / \mathrm{dm}^{3}, S(t=8) \doteq 0.59 \mathrm{~g} \mathrm{VS} / \mathrm{dm}^{3}$, $S(t=15) \doteq 0.02 \mathrm{~g} \mathrm{VS} / \mathrm{dm}^{3}$. These results show the downward trend of the substrate concentration. After 15 days since the hydrolysis started there is almost none substrate left.

b) In this case, we use the same mathematical formula as previously, but we substitute $\frac{1}{4} S_{0}$ for $S$ on the left side of the equation:

$$
\begin{gathered}
\frac{1}{4} S_{0}=S_{0} \cdot e^{-k_{1} t} \\
\frac{1}{4}=e^{-k_{1} t} \\
\ln \left(\frac{1}{4}\right)=-k_{1} \cdot t \\
t=-\frac{\ln \left(\frac{1}{4}\right)}{k_{1}}
\end{gathered}
$$

We substitute $k_{1}=0.5$ day $^{-1}$ into this formula and we obtain the result: $t \doteq 2.77$ day. It means that the substrate concentration falls to $1 / 4$ of its initial value approximately after 2 days and 18.5 hours. 
Note: all results of this exercise are in accordance with the orange curve in the graph in Figure 2 which represents time dependency of substrate concentration.

Calculation exercise 2: Time dependence of methane production [10, 12].

In a batch experiment, methane is produced from substrate. Maximum yield of methane from this substrate $B_{0}=0.36 \mathrm{dm}^{3} \mathrm{CH}_{4} / \mathrm{g} \mathrm{VS}$, the kinetic parameter $k_{4}=0.6$.

Tasks:

a) Calculate the yield of methane $V_{B}$ after 2, 4, 8 and 15 days since the experiment started.

b) Determine when the yield of methane $V_{B}$ is equal to $90 \%$ of the maximum yield.

Solution:

a) Production of methane from the substrate is described by a differential equation

$$
\frac{d V_{B}}{d t}=B_{0} \cdot k_{4} \cdot e^{-k_{4} t}
$$

which can be written in an integral form

$$
V_{B}=B_{0} \cdot\left(1-e^{-k_{4} t}\right)
$$

Into this equation we substitute $B_{0}=0.36 \mathrm{dm}^{3} \mathrm{CH}_{4} / \mathrm{g} \mathrm{VS}, k_{4}=0.6$ and gradually $t=2,4,8$ and 15 day for particular periods. After the calculation we obtain the results: $V_{B}(t=2) \doteq 0.25 \mathrm{dm}^{3} \mathrm{CH}_{4} / \mathrm{g} \mathrm{VS}, V_{B}(t=4) \doteq 0.33 \mathrm{dm}^{3} \mathrm{CH}_{4} / \mathrm{g} \mathrm{VS}$, $V_{B}(t=8) \doteq 0.36 \mathrm{dm}^{3} \mathrm{CH}_{4} / \mathrm{g} \mathrm{VS}, V_{B}(t=15) \doteq 0.36 \mathrm{dm}^{3} \mathrm{CH}_{4} / \mathrm{g}$ VS. These results show that the yield of methane approaches the value $B_{0}$ with increasing time. After 8 days since the experiment started the yield of methane is almost at its maximum value.

b) In this case, we use the same mathematical formula as previously, but we substitute $\frac{9}{10} B_{0}$ for $V_{B}$ on the left side of the equation:

$$
\begin{gathered}
\frac{9}{10} B_{0}=B_{0} \cdot\left(1-e^{-k_{4} t}\right) \\
\frac{9}{10}=1-e^{-k_{4} t} \\
e^{-k_{4} t}=\frac{1}{10} \\
-k_{4} \cdot t=\ln \left(\frac{1}{10}\right) \\
t=-\frac{\ln \left(\frac{1}{10}\right)}{k_{4}}
\end{gathered}
$$

We substitute $k_{4}=0.6$ into this formula and we obtain the result: $t \doteq 3.84$ day. It means that the yield of methane is equal to $90 \%$ of the maximum yield approximately after 3 days and 20 hours since the experiment started.

Note: all results of this exercise are in accordance with the violet curve in the graph in Figure 2 which represents time dependency of methane production. 
Calculation exercise 3: Using Chen-Hashimoto mathematical model to determine methane yield and retention time in a continuous methanization process [8, 9].

Agricultural substrate whose main component is cattle slurry is used for production of methane in a continuous process. Maximum yield of methane from this substrate $B_{0}=0.20 \mathrm{~m}^{3} \mathrm{CH}_{4} / \mathrm{kg}$ VS, Hashimoto kinetic constant $K=1.05$ and maximum growth rate of methanogenic microorganisms $\mu_{\max }=0.33$ day $^{-1}$.

Tasks:

a) Let us assume that the entire volume of the substrate is replaced in 10 days. Calculate the volumetric production of methane $V_{M}$.

b) It is needed to achieve the volumetric methane production $V_{M}=0.11 \mathrm{~m}^{3} \mathrm{CH}_{4} / \mathrm{kg}$ VS. Determine the value of retention time $H$ which ensures this methane production.

Solution:

a) The volumetric production of methane from this type of substrate can be calculated by the Chen-Hashimoto formula:

$$
V_{M}=B_{0} \cdot\left(1-\frac{K}{H \cdot \mu_{\max }+K-1}\right)
$$

Into this formula we substitute $B_{0}=0.20 \mathrm{~m}^{3} \mathrm{CH}_{4} / \mathrm{kg} \mathrm{VS}, K=1.05$ and $\mu_{\max }=0.33 \mathrm{day}^{-1}$. The information that the entire substrate volume is replaced in 10 days means that the retention time is 10 days, so we substitute $H=10$ day into the formula. After the calculation we obtain the value of volumetric methane production $V_{M} \doteq 0.14 \mathrm{~m}^{3} \mathrm{CH}_{4} / \mathrm{kg}$ VS.

b) In this case, we rewrite the Chen-Hashimoto formula into a form:

$$
H=\frac{1}{\mu_{\max }} \cdot\left(\frac{B_{0} \cdot K}{B_{0}-V_{M}}-K+1\right)
$$

and substitute $\mu_{\max }=0.33$ day $^{-1}, B_{0}=0.20 \mathrm{~m}^{3} \mathrm{CH}_{4} / \mathrm{kg} \mathrm{VS}, \quad K=1.05$ and $V_{M}=0.11 \mathrm{~m}^{3} \mathrm{CH}_{4} / \mathrm{kg}$ VS. After the calculation we obtain the result $H \doteq 6.92$ day which means that the required retention time is nearly 7 days.

\section{Discussion}

In this paper, a new approach to teach physically and technically oriented subjects in bachelor's degree programs at the University of Hradec Kralove is introduced. Our effort is to complement theoretical lectures with practical exercises and excursions to relevant companies. Interconnection of these teaching methods brings many benefits. During theoretical lectures the students obtain necessary theoretical knowledge which they subsequently use in practical lessons, so they recognize the importance of the theory as well as they learn to use it for solving real problems. The need to support hands-on trainings in the process of education is expressed e.g. in [13] where the usefulness of practical familiarizing technical students with modern sensor systems and data analysis and visualization is expressed. During hands-on trainings the students gain practical experience and ability to work autonomously which is by employers often appreciated more than mere theoretical knowledge: if a job seeker has some practical skills in the desired field, the employer does not have to invest so much time and money into his or her trainings, which 
is a considerable advantage for this job seeker. Solving practical problems in teams enhances students' social skills and ability to collaborate [13] which is also appreciated by employers.

The importance of obtaining practical skills before entering a job is emphasized in [14] where it is stated that graduates with physico-technical focus often have to spend a lot of time both within their work hours and in their leisure to improve the skills needed in their employment. This is really challenging especially when the employee has to deliver the work results within short deadlines, which is quite common today.

The fact that the transfer of physical-technical knowledge gained at universities to employment is a problem also in other European countries is documented e.g. in the study [15] where the authors show that the graduates often have not enough discipline-specific competencies or they struggle to identify their own competencies so it is difficult for them to find an appropriate job.

Finally, during the excursions the students see how the taught topics are applied in a real workplace, which is motivating for them too. Because more companies are visited, the students also get to know different work environments. Comparison of an employee situation in companies will help them in selection of a desired professional position in future job lookups. Furthermore, the students can establish contacts with their potential employers already during their studies.

As an example of the proposed educational approach we included here our materials for teaching the process of biogas production in biogas plants. It is a topical issue which offers good job opportunities for the future. The theoretical part of the course consists in explanation of biochemical processes which take place during biogas production; also important mathematical relationships needed for practical calculations are included here. Article [15], however, warns against excessive using of mathematical formalism which prevents students from understanding the root of the studied problematics. It can lead to simply memorizing mathematical formulas with the risk of applying them incorrectly while diminishing critical thinking about the solved task. Accordingly, the students should first explore in detail the meaning behind a given mathematical formula before starting to use it.

To avoid such problems with wrong applying of mathematical formulas and to ensure correct understanding of our topic, we have created a new graphical teaching scheme which puts into context the biochemical processes and their quantification using mathematical models. The scheme is supplemented by several exercises on using mathematical models for solving practical process problems. Besides analytical solving of tasks, the students also learn to analyze and display data measured during the described biochemical processes. All these acquired knowledge and skills are crowned by visiting a biogas plant where the students see the entire methanization technology including devices used for measuring process parameters.

In this work we try to refute the claim stated in [16]: "in theory yes, but not in practice". We consider that the proposed approach will improve the quality of teaching physically and technically oriented subjects increase the students ' interest in the taught topics and also employability of the graduates.

\section{Conclusions}

An innovative approach to realization of the teaching program "Physico-technical Measurements and Computer Technology" is required to fulfil labour market expectations 
and to make this subject more attractive for students. Student's activities in theoretical and practical areas constitutes comprehensive source of knowledge and skills required in real life job. Joined theoretical and practical knowledge gained by students, reinforced by the skills developed during task analysis followed by their solution, provides the future graduate higher quality abilities and a better position in the labour market.

\section{Acknowledgements}

This work continues with the participation of students from the Faculty of Natural Sciences and Technology, University of Opole and the Faculty of Science, University of Hradec Kralove in the frame of their academic exchange, professional internships in Agricultural biogas plant Agrodruzstvo Lhota pod Libcany CZ, EMPLA Hradec Kralove CZ, EMITOR Opole PL and consultations with IDEA-ENVI Valasske Mezirici CZ. This work is supported by the specific research project PřF UHK no. 2115/2016.

\section{References}

[1] Kříž J, Hyšplerová L, Trnková L, Lyčka A, Vybíral B, Hlúbik J, et al. Innovation in study of physical and technical measurements. Czech-polish cooperation of universities. Chem Didact Ecol Metrol. 2014;19(1-2):37-45. DOI: 10.1515/cdem-2014-0003.

[2] Igliński B, Piechota G, Buczkowski R. Development of biomass in polish energy sector: an overview. Clean Techn Environ Policy. 2015;17(2):317-329. DOI: 10.1007/s10098-014-0820-x.

[3] The agricultural biogas plants in Poland. Oil and Gas Institute - National Research Institute Poland. 2014. https://www.globalmethane.org/documents/Poland-Ag-Biogas-Plants-April-2014.pdf.

[4] Lebuhn M, Munk B, Effenberger M. Agricultural biogas production in Germany - from practice to microbiology basics. Energy, Sustainability Society. 2014;4:10. DOI: 10.1186/2192-0567-4-10.

[5] Weiland P. Biogas production: Current state and perspectives. Appl Microbiol Biotechnol. 2009;85(4):849-860. DOI: 10.1007/s00253-009-2246-7.

[6] Bond T, Templeton MR. History and future of domestic biogas plants in the developing world. Energy Sust Develop. 2011;15(4):347-354. http://www.sciencedirect.com/science/article/pii/S0973082611000780.

[7] El Monayeri DS, Atta NN, El Mokadem SM, Aboulfotoh AM. Improvement of anaerobic digesters using pre-selected micro-organisms. Inter Water Technol J. 2013;3(1):45-59. http://iwtj.info/wp-content/ uploads/2013/04/V3-N1-P5.pdf.

[8] Chen YR, Hashimoto AG. Substrate utilization kinetic model for biological treatment process. Biotechnol Bioeng. 1980;22(10):2081-95. DOI: 10.1002/bit.260221008.

[9] Ghatak MD, Mahanta P. Comparison of kinetic models for biogas production rate from saw dust. Int J Res Eng Technol. 2014;3(7):248-254. http://esatjournals.net/ijret/2014v03/i07/IJRET20140307042.pdf.

[10] Echiegu EA. Kinetic models for anaerobic fermentation processes - A review. Amer. J. Biochem. Biotechnol. 2015;11(3):132-148. DOI: 10.3844/ajbbsp.2015.132.148.

[11] Yu L, Wensel PC, Ma J, Chen S. Mathematical modeling in anaerobic digestion. J Bioremed Biodeg. 2013;S4(003):1-12. DOI: 10.4172/2155-6199.S4-003.

[12] Kříž J, Hyšplerová L, Smolík M, Eminger S, Vargová A, Keder J, et al. Modelling of emissions from large biogas plants. Chem Didact Ecol Metrol. 2015;20(1-2):49-58. DOI: 10.1515/cdem-2015-0005.

[13] Mirkouei A, Bhinge R, McCoy C, Haapala KR, Dornfeld DA. A pedagogical module framework to improve scaffolded active learning in Manufact Eng Educ. Procedia Manufacturing. 2016;5:1128-1142. DOI: 10.1016/j.promfg.2016.08.088.

[14] Nielsen TB, Holmegaard HT. From university student to employee. Int J Innovation Sci Math Educ. 2016;24(3):14-30. https://www.researchgate.net/ publication/308889074.

[15] Smigiel E, Sonntag M. A paradox in physics education in France. Phys Educ. 2013;48(4):497. DOI: 10.1088/0031-9120/48/4/497. http://iopscience.iop.org/article/10.1088/0031-9120/48/4/497/meta.

[16] Korpela A, Tarhasaari T, Kettunen L, Mikkonen R, Kinnari-Korpela H. Towards deeper comprehension in higher engineering education: rethinking "in theory yes, but not in practice". Europ J Sci Math Educ. 2015;3(4):390-407. https://www.researchgate.net/publication/282661587. 


\title{
INNOWACYJNY PROGRAM EDUKACYJNY DOTYCZĄCY WYTWARZANIA BIOGAZU REALIZOWANY NA UNIWERSYTETACH W HRADEC KRÁLOVÉ (CZ) I OPOLU (PL)
}

\author{
${ }^{1}$ Uniwersytet Hradec Králové, Republika Czeska \\ ${ }^{2}$ Samodzielna Katedra Biotechnologii i Biologii Molekularnej, Uniwersytet Opolski, Opole, Polska
}

\begin{abstract}
Abstrakt: W ostatnim czasie rośnie nacisk na budowę biogazowni rolniczych, szczególnie w czesko-polskim regionie przygranicznym. Jest to region, gdzie występują duże obszary gruntów rolnych mogących służyć do zasilania biogazowni. Strategia ta powinna przyczynić się do harmonizacji wspólnej polityki rolnej Unii Europejskiej. W związku z powyższym wzrasta również potrzeba wykształcenia wykwalifikowanych operatorów tych stacji. Pierwsza część pracy obejmuje prezentację akademickiego programu edukacyjnego w dziedzinie fermentacji beztlenowej odpadów i wytwarzania biogazu pochodzącego z produkcji rolnej. Zaprezentowano część innowacyjnego podejścia, które wykorzystywane jest w programie nauczania „Pomiary fizyko-techniczne oraz technologie komputerowe” na Wydziale Nauk Przyrodniczych Uniwersytetu Hradec Kralove, a także w edukacji studentów Wydziału Przyrodniczo-Technicznego Uniwersytetu Opolskiego. Wymagania te mają sprostać oczekiwaniom rynku pracy i uczynić kierunek studiów bardziej atrakcyjnym. Powiązanie przygotowania teoretycznego i praktycznego studentów tworzy kompleksowe źródło wiedzy i kształtuje umiejętności niezbędnych do pracy w biogazowniach. Zarówno wiedza teoretyczna, jak i umiejętności praktyczne zdobyte przez studentów, wzbogacone o umiejętności analizy zadań, a następnie ich rozwiązania, zapewnią przyszłym absolwentom większe możliwości i lepszą pozycję na rynku pracy.
\end{abstract}

Słowa kluczowe: biogazownie, pomiary ciągłe, modelowanie 